\title{
A Study on Problems of Minority Students in English Learning
}

\author{
Yan Zhao \\ Nanchang Institute of Science \&Technology, Nanchang Jiangxi 330108, China
}

Keywords: Ethnic minorities; English learning; Language environment

\begin{abstract}
In the current world characterized by economic globalization, English as an international communicative language has attracted worldwide attention. In our country, learning English is regardedas important as learning Chinese. Most tests involve English, andEnglish is even considered as a sign of one's quality and level. Because ethnic minority students in our country live in mountainous areas, theysuffer traffic inconvenience and lack information. Barriers to English study are thus formed, makinggreat difficulties to minority students in learning English. In view of this fact, the language environment, the English language learning, cultural background and confidence establishment in learning English and so on, will play a significant role in improving the minority students'English teaching level.

With the rapid development of society and economy as well as the increasingly frequent international exchanges, English has become an indispensable tool for people to exchange ideas, communicate information, and do social and scientific research. English, as a worldwide language,becomes more acceptable by many countries in the world and there are 10 countries using English as their official language. Data shows that in the worldwide Internet business, 84\% of the total amount of communication is made in English, followed by German, Japanese and French. In addition, many countries take English as their main teaching language. After accession to the WTO, China has taken the initiative to participate in international competition in line with the trend of economic globalization. In developing the economy, enhancing international competitiveness and striving for international mutual understanding, English is the tool that can not be ignored. At present, English learning becomes increasingly popular. The appearance of various English certificates, the promotion of titles and all kinds of entrance examinations all reflect the importance of English in the whole society. For modern college students, English language gradually has the same status as their mother tongue, and plays a vital role in social communication and cultural learning. However, there are many differences between Chinese college students and English speaking students in terms of language environment, for example, ethnic habits, lifestyle, learning methods and so on. For those minority students in our countrywhose mother tongue is not Chinese, apart from the above differences, there will be more difficulties in learning English through Chinese.
\end{abstract}

\section{Minority students' difficulties and obstacles in English learning}

Language learning can not be separated from language environment. A good one can provide the necessary access to language learning and the opportunity to develop language skills. Most minority students live in mountainous areas with limited transportation, little contact with the outside world, hard life and little knowledge exchange. During their growth, dialect is chosen to be used in daily communication. Traffic difficulties in remote mountain areasset up obstacles and block communications with the outside world.

Some children in the mountains even do notunderstand Chinese, let alone speaking English. 
Minority students in junior school, high school, have already learned English courses, but their parents, relatives and friends almost never heard what English is.

Learning English in such an environment affects the efficiency of learning. Without language environment, it is impossible to learn English well, because language environment is essential for human beings to acquire language. Due tothe relatively backward economy and culture in ethnic minority areas, they have little opportunities to access to English, thus minority language becomes a dominant language in the region and is used in a variety of communications. Since there are semantic differences between minority language and Chinese, teaching Chinese via English is inevitably difficult. At the same time, minority students need to learn English through Chinese which leads to more semantic confusion and obstacles. Under these conditions, it is hard for them to learn English and communicate in English. They feel very unaccustomed and feel uncomfortable because of their bad Chinese. For them,it is testing to understand Chinese expressions used under certain conditions, let alone learningEnglish through Chinese.

In China, there are 56 ethnic groups. Each group is characterized by their own unique culture and produces different degree of difficulties for English.

Language as a carrier of cultural imagination and culture, it is not only a tool for communication, but also one of the important means of national culture.It doesn't only carry and transfer people's thoughts and feelings, but also reflectthe national character and the evolution of human civilization. Minority students have different cultural backgrounds, so English teaching in ethnic minority areas generally uses minority language and Chinese these two language teaching modes. It can be said that the national language is their mother tongue, so Chinese is their first language, and English is their second language. Ethnic minority students, Chinese Hansand English speaking people live in different cultural backgrounds, and these cultures collide with each other, which add difficulty to learning English, because eastern culture is different from western culture, and minority culture differs from Han culture. Those differences are caused by diverse historical development, ideology and values of different forms and largely reflected in language, therefore sometimes even the same expression has distinct meanings in different cultures.So misunderstandings usually happen.

Since the ethnic minorities' particular living status, the government often expresses respect to their national characteristicsby empowering them the right of regional autonomous management. In addition, the rulers of the ethnic minoritiesaccount for generations of long-term discrimination and exclusion and rarely contact with the mainland and coastal areas,thus they lack communication and exchange with outside world. At the same time, the difficulties in the exchange of information have led to the lack of awareness of the importance of English education among the minority peoples in poor and backward areas, and some still didn't realize it so far. In addition, special household production, productivity and production relations work as a unit resulting in the disregard of the education in ethnic minority areas. Many people regard education as an investment without any return, so learning English for them is far more useless. This concept seriously hinders the attention to the importance of English learning in ethnic minority areas.

The exclusion of foreign cultures of ethnic minorities is not conducive to English learning. For a long time, due to the restriction of history, cultural and natural environment factors such as the slow social development of minority regions, low level of productivity, traditional culture which lasts thousands of years and the existence of ecological system. People in the minority areas, because of different ethnic origins, keep a long-term preservation of their unique characteristics of the national culture. This closed cultural system has a strong degree of repulsion to foreign cultures. English as one of the representatives of foreign culturebelongs to the western cultural style featured 
with openness, while the minority culture is conservative and self-sealing which are bound to cause a lot of conflicts.In general, it seems that minority students have congenital disorders in English learning.

\section{English teaching reform and measures for minority students}

Reading materials can provide learners with colorful, vivid and interesting language input. The purpose of reading should not rest on improving language ability, but be regarded as a process of enriching humanistic ideas, expanding horizons and pursuing intellectual satisfaction. Extensive reading of the original English newspapers and articles, the beautiful language of English books, the rhythm, and the discreet wording, can improve the sense of language and the overall level of English.

Hollywood movies are popular all over the world, but there are many doubts for students, especially minority students to watch these English movies. In fact, movies can bring learners into a "real" context. Language is the carrier of culture. By watching the original film, learners can better understand the cultural phenomena in language and the relationship between language and culture. In the process of watching, we should not only pay attention to learning fresh daily life expressions, but also understanding the unique culture of English. In this way, watching movies is not only a simple process of entertainment and recreation, but also a process of enriching English language and cultural knowledge and improving theEnglish ability in a comprehensive way.

The popularity and use of computers have greatly enriched and expanded foreign language learning resources and means, providing a material foundation for the construction of English language environment. On the Internet, learners can not only searchfor various latest information about politics, economy, science and technology, culture and sports, but also pick up beautiful English songs, and even listen to the World Summit for celebrity speeches. The expressions, graphics and sound effects on the Internetmakea good language environment.

\section{Understand English culture background and strengthen cultural communication}

In Ethnic Minority English teaching, cultural education is emphasized, and students' cultural background knowledge is introduced and discussed. It is necessary to guide students to pay attention to and accumulate materials about cultural background, social customs, social relations and so on when they read literature and newspapers. Literature is the most vivid and abundant material to understand a nation's cultural characteristics, customs, social relations and other aspects. Teachers should choose some literary works that will enable studentsto improve the communication skills in a short period of time.Since the structure and vocabulary of literary works differ from those of books from minority areas which have distinct social and cultural factors, teachers should make effective use of such materials.

In the classroom teaching, teachers must not only pay attention to the correct language forms, but also to the proper use of language, which undoubtedly puts forward higher requirements for teachers. For example, let students write situational dialogues and do role playing, so that students can pay more attention to the habits of English speaking countries in terms of language, intonation, facial expressions and gestures.

\section{Develop interest in learning English.}

In order to learn English well, we should cultivate interest in learning English. Psychologists believe that the best motivation to learn is to have an intrinsic interest in the subject. 
The only way to develop interest in learning English is to make the process of English learning enjoyable. It seems that English learning is not a heavy load, but brings us endless enjoyment. After the students have certain ability of English reading, they can learn some sayings, proverbs, songs, stories or essays in science and technology. They can choose reading materials according to their hobbies. Some students read English materials to collect stamps. Football lovers read news about foreign players. Movie lovers are interested in introducing foreign films and movie stars.Everyone can find something they are interested in.

Squeeze out timeand find materials you are interested in. It will not only be helpful to learn English, but also produce pleasure during the process. Taking part in extracurricular activities is also an important means to cultivate interest in learning, such as singing English songs, reading poems, telling stories, guessing riddles, rehearsing English skits, and holding Englishparties, etc.Active participation in various competitions is also helpful, such as English contests, recitation contests, singing contestsand speech contests. These interesting activities will make English learning more colorful.

\section{Conclusion}

English is becoming more and more important as a tool for international communication in an increasingly globalized economy. English learning has won a common concern among people at all ages and status. However, there are great difficulties in English learningfor minority students because of the obstacles of living conditions, traffic conditions, ethnic customs, historical and cultural backgrounds. In order to improve the quality of minority students' English learning, developing the teaching level in the process of English teaching in ethnic minorities, creating a good language environment, cultivating students' interest in learning English, strengthening cultural exchanges, and building up students' confidence in learning English, will play a significant role.

\section{References}

[1] Mengzi H E, Hong X. On the Position and Function of Core Values in the Construction of National Cultural Soft Power[J]. Studies in Sociology of Science, 2015, 6(1).

[2] Tan Z J. Thought on the Research of the "Soft Power" and the Construction of National Cultural Security System[J]. Oriental Forum, 2009.

[3] Gui-Rong P. Rational Thought on Enhancing the National Cultural Soft Power[J]. Journal of Heilongjiang College of Education, 2008.

[4] Tagami K, Nochi K, Moribayashi H, et al. Rational Thought on Strengthening College Honest and Clean Government Cultural Construction[J]. Journal of Southwest University for Nationalities, 2006, 11(2):205-216.

[5]Pei Q. On the Path of Enhancing the Soft Power of Red Culture in the Perspective of Cultural Confidence[J]. Journal of the Party School of Shengli Oilfield, 2016. 